NEW DIRECTIONS IN THEATRE

General Editor JULIAN HILTON 
NEW DIRECTIONS IN THEATRE

Published titles

FEMINISM AND THEATRE

Sue-Ellen Case

IMPROVISATION IN DRAMA

Anthony Frost and Ralph Yarrow

NEW DIRECTIONS IN THEATRE

Julian Hilton

PERFORMANCE

Julian Hilton

THEATRE AS ACTION

Lars Kleberg

TRANSPOSING DRAMA

Egil Tornquist

Forthcoming titles

REPRESENTATION AND THE ACTOR

Gerry McCarthy

SEMIOTICS OF THE DRAMATIC TEXT

Susan Melrose 


\section{Theatre as Action}

Soviet Russian Avant-Garde Aesthetics

\section{LARS KLEBERG}

Translated from Swedish by Charles Rougle 
Lars Kleberg 1980, 1993

Softcover reprint of the hardcover 1st edition 1993

All rights reserved. No reproduction, copy or transmission of this publication may be made without written permission.

No paragraph of this publication may be reproduced, copied or transmitted save with written permission or in accordance with the provisions of the Copyright, Designs and Patents Act 1988, or under the terms of any licence permitting limited copying issued by the Copyright Licensing Agency, 90 Tottenham Court Road, London W1P 9HE.

Any person who does any unauthorised act in relation to this publication may be liable to criminal prosecution and civil claims for damages.

First published in Swedish 1980 by

Bokförlaget PAN/Norstedts

Stockholm

First published in English 1993 by

THE MACMILLAN PRESS LTD

Houndmills, Basingstoke, Hampshire RG21 2XS

and London

Companies and representatives

throughout the world

ISBN 978-0-333-56817-0

ISBN 978-1-349-22867-6 (eBook)

DOI 10.1007/978-1-349-22867-6

A catalogue record for this book is available from the British Library 


\section{Contents}

General Editor's Preface

Preface

vii

ix

PART I AVANT-GARDE ART AND THE PROJECT OF CULTURAL REVOLUTION

1 Iconoclasm and Festival

2 The Project of Cultural Revolution $\quad 8$

In search of a cultural policy 8

Culture as collective creativity: the Proletkult $\quad 10$

The professional cultural revolution:

the avant-garde 14

The crisis of 1920-1921 and the defeat of the maximalists

'Lenin's view of culture' 21

Production art 23

3 Down with the Fetishes! 27

The modern cult of the statue $\quad 27$

Statues and the early Soviet government 28

The avant-garde and iconoclasm $\quad 30$

Tatlin's anti-monument $\quad 32$

Permanent iconoclasm 34

PART II THEATRE AS ACTION

4 Theatre as Example $\quad 38$

5 The Semiotics of Theatre 40

Theatrical doctrines and theatrical theory 40

The sign function of the theatre 42

Stage, auditorium, society 44

6 Stage and Auditorium in the Russian Modernist Theatre

Three types of theatre $\quad 50$ 
The people's theatre before 1917

The people's theatre utopia after the October Revolution

7 Theatre Constructivism

Meyerhold and the rationalisation of theatre 65

$\begin{array}{ll}\text { Towards biomechanics } & 67\end{array}$

Action and expressiveness $\quad 70$

'The factory for the new man' 72

8 The Theatre of Attractions $\quad 77$

The circus as laboratory $\quad 77$

From sign to action $\quad 82$

The theatre as 'processing of the spectator' 84

Theatre at the factory $\quad 86$

$\begin{array}{ll}\text { Striking facts } & 89\end{array}$

9 The Audience as Myth and Reality 93

The crisis of the people's theatre utopia 93

Audience responses: how? who? why? 94

Two concepts of the audience 100

10 The Theatre as an Arena for Discussion 103

The divided audience 103

Biology and society 104

'Love on the operating table' 108

Brecht, Tretyakov, and the instructive theatre 109

11 The Provisional Abdication of Total Theatre 114

POSTSCRIPT: THE AVANT-GARDE AND HISTORY 120

$\begin{array}{ll}\text { Notes } & 127\end{array}$

Biographical Notes $\quad 147$

$\begin{array}{lr}\text { Index } & 149\end{array}$ 


\section{General Editor's Preface}

In the past ten years, Theatre Studies has experienced remarkable international growth, students seeing in its marriage of the practical and the intellectual a creative and rewarding discipline. Some countries are now opening school and degree programmes in Theatre Studies for the first time; others are having to accommodate to the fact that a popular subject attracting large numbers of highly motivated students has to be given greater attention than hitherto. The professional theatre itself is changing, as graduates of degree and diploma programmes make their way through the 'fringe' into established theatre companies, film and television.

Two changes in attitudes have occurred as a result: first, that the relationship between teachers and practitioners has significantly improved, not least because many more people now have experience of both; secondly, that the widespread academic suspicion about theatre as a subject for study has at least been squarely faced, if not fully discredited. Yet there is still much to be done to translate the practical and educational achievements of the past decade into coherent theory, and this series is intended as a contribution to that task. Its contributors are chosen for their combination of professional and didactic skills, and are drawn from a wide range of countries, languages and styles in order to give some impression of the subject in its international perspective.

This series offers no single programme or ideology; yet all its authors have in common the sense of being in a period of transition and debate out of which the theory and practice of theatre cannot but emerge in a new form.

JuLian HiLton 


\section{Preface}

In the debates on 'revolutionary art' or 'cultural revolution' in the 1920s in Soviet Russia, several discourses seem to be intertwined, to run parallel, and even, at times, to coincide. The same can be said of the concept of the homogeneous and 'representative' auditorium during the period of theatrical modernism. One of the primary tasks of the analysis in the present book has been to distinguish and contrast different concepts, even at points where they sometimes seem to be using the same words. This has called for a somewhat archaeological approach of reconstruction and conjecture. Contemporaries of the period in question perhaps found it easier to distinguish between positions which at a historical distance tend to be swallowed up in a single '1920s discourse'. For example, the avant-gardists, the Proletkult activists, and the few Bolsheviks interested in art were in reality associated with quite different cultural contexts which automatically guaranteed various decodings of their sometimes almost identical phraseology. The reader of today is necessarily obliged to adopt an approach that reactivates these contexts and sharpens such distinctions.

If distinguishing and differentiating is the first of the two basic strategies of this study, the second seems to lead in the opposite direction. For the sake of conclusive comparisons, the analysis sometimes simplifies, and sometimes deliberately overexposes phenomena of rather different levels (for example, the theatrical practice of naturalist staging and the utopian programme of 'ritual theatre'). In retrospect, some of these typological strictures may appear somewhat 'anatomical', but because they are essential to the composition of the book, I have chosen to leave them largely unaltered from the original version.

In revising the text for the English edition I have generally tried to avoid superficially 'updating' the frame of reference; my afterthoughts are to be found in the Postscript. Certain passages have been shortened, some new paragraphs added, and the chapter 'The Provisional Abdication of Total Theatre' is new. The bibliographic references have been thoroughly revised with a view to the English-speaking reader. Apart from these changes, the central arguments of the book stand as they were formulated fifteen years ago.

Re-reading the original 1977 Swedish edition of the book, I have noted (with mixed feelings of satisfaction and disappointment) that the wealth 
of research on the Russian avant-garde and the Soviet 1920s published in the meantime has not rendered my treatment of the basic issue obsolete: the interrelationship between art and the public, or, in the language of semiotics, the pragmatic aspect of art. Furthermore, what must be considered the new standard work in the field, Konstantin Rudnitsky's strictly inductive survey Russian and Soviet Theatre. Tradition and the Avant-Garde (1988) seems to lend support both to the typology proposed here and to my strong emphasis on the Wagnerian heritage and the popular mixture of symbolism and communism, aspects which in 1977 were not commonly treated either in Soviet or in Western scholarship.

The reservations the book may raise in retrospect probably have to do with its limited scope. The focus on the politicised segment of the avantgarde viewed as the centre of Russian cultural life was obviously the choice of a sympathiser - a sympathiser, however, who was more interested in analysing the crisis of the movement than in proposing an uncritical reception of it. Thus the book was and still is not an attempt to write the history of the Soviet Russian theatre of the 1920s. Its composition is determined by the theme: the self-reflection of a political avantgarde art situated, roughly speaking, in a field delimited by the names of Vsevolod Meyerhold and Bertolt Brecht. The choice of both subject and method has obvious roots in the perspective of the 1970s, but this is not the only reason my book is out of tune with the current 'about-face' trend in Soviet cultural history, which proposes a general inversion of former established hierarchies and proportions and sometimes ends in little more than a new hagiography: instead of Mayakovsky - Mandelstam; instead of Meyerhold - Tairov; instead of Lenin - Berdyayev; and so on. My aim was and is not to contribute to such new hierarchy-building. If there is today a specific context to which the study of the 1920s transformations of certain avant-garde myths relates, it is probably that of the post-modernist debate.

In the preface to the first edition of this book I quoted the Swedish critic Ulf Linde, who remarked: 'What you are not able to translate, you haven't really understood.'

My friend Charles Rougle's translation of the text is based on a true understanding of the subject, and has certainly provoked me to clarify or revise a number of points. For different reasons - one of them being the geographical distance that now separates us - we have not been able to finish work on the book in the close collaboration in which it was begun. 
Nevertheless, I want to thank Professor Rougle for his painstaking labours, which - once again - have helped a Swedish scholarly work appear in an English that is clearer and more intelligible than its original version, perhaps, deserves.

Also, I would like to thank Dr Richard Taylor of the University College of Swansea for reading the penultimate version of the manuscript and for providing valuable comments before it was delivered to the careful editors of Macmillan. I am especially indebted to Professor Julian Hilton, general editor of the New Directions in Theatre series, for his inspiring comments and patient support during the revision of the book. Any remaining flaws or obscurities, of course, are entirely my responsibility.

Special research for chapter 9 has been made possible by a short-term grant from the Kennan Institute of Advanced Russian studies in Washington, DC.

The translation of the book has been made possible by a grant from the Swedish Council for Research in the Humanities and Social Sciences, which is hereby gratefully acknowledged.

Moscow - Funbo,

August 1991

L. K. 